\title{
SOCIAL ENTREPRENEURSHIP EMPOWERMENT IN THE INDONESIAN ARCHIPELAGIC COMMUNITIES
}

\author{
Henny H. Br Dalimunthe $\left.{ }^{*}\right)$, Anan Sutisna*), Karnadi*), Elais Retnowati*), and Ahmad Tijari*) \\ ${ }^{*}$ Faculty of Science Education, Universitas Negeri Jakarta \\ Jl. R.Mangun Muka Raya No.7, Rawamangun, Jakarta 13220, Indonesia
}

\begin{abstract}
Poverty and unemployment problems are some of the problems in several Asian countries, especially in Indonesia. The Indonesian government and private institutions have made various efforts to overcome the problems through various empowerment programs. However, the results have not been optimal in reducing poverty and unemployment, especially in archipelagic areas that are geographically difficult to reach. This research aimed to describe the conceptual model of social entrepreneurship in the Indonesian archipelagic communities. The method used was qualitative and the data were collected using interviews and observation. The empirical findings showed that there were several components in developing social entrepreneurship, namely human and natural resource potentials, a motivator, mutual cooperation values, and community partners. In conclusion, social entrepreneurship could empower the archipelagic communities through social values built on community participation through a group approach by developing local potentials, motivation, and mutual cooperation values.
\end{abstract}

Keywords: archipelagic communities, mutual cooperation values, social entrepreneurship, tourism conscious group

Abstrak: Masalah Kemiskinan dan penggangguran merupakan salah satu masalah di beberapa negara Asia terutama di Indonesia. Pemerintaha di Indonesian beserta lembaga swasta telah melakukan berbagai upaya untuk mengatasi masalah tersebut dengan berbagai program pemberdayaan. Namun hasil upaya tersebut belum optimal menekan tingkat kemiskinan dan pengangguran terutama di daerah kepulauan yang secara geografis sulit terjangkau. Tujuan penelitian untuk menggambarkan model konseptual kewirausahaan sosial pada masyarakat kepulauan. Metode penelitian menggunakan pendekatan kualitatif, pengambilan data dengan teknik wawancara dan observasi. Hasil temuan secara empiris terdapat beberapa komponen dalam mengembangkan kewirausahaan social yaitu komponen potensi sumber daya manusia dan alam, motivator, nilai gotong royong dan mitra masyarakat. Kesimpulannya Kewirausahaan sosial dapat memberdayakan masyarakat pulau melalui nilai sosial yang dibangun atas partisipasi masyarakat melalui pendekatan kelompok dengan mengembangkan potensi lokal, motivasi dan nilai gotong royong.

Kata kunci: gotong royong, kelompok sadar wisata, kewirausahaan sosial, masyarakat kepulauan, motivator

${ }^{1}$ Corresponding author:

Email: henny_dalimunthe@unj.ac.id 


\section{INTRODUCTION}

The poverty problem becomes a barrier to the achievement of Sustainable Development Goals (SDGs) in several Asia and Pacific countries with an annual urbanization rate of $3 \%$. Based on the semi-annual report of Global Economic Prospects, among the 260 million Indonesian population, there were still around 25,9 million people living below the poverty line or around $29,78 \%$ of the population were still vulnerable to falling into poverty. Given the challenges, the policy applied by developing countries in reducing poverty using economic growth is not enough to tackle poverty (Moges, 2013). The Indonesian people living below the poverty line were spread in multiple urban, rural, and archipelagic areas. Indonesia is listed as the largest archipelago country with 16.056 islands and has been verified and reported to the United Nations (UN) in the 11th United Nations Conference On Standardization Of Geographical Names (UNCSGN) in New York in 2017.

This research was conducted because the poor, in terms of income, still have roles, namely as consumers, producers, and co-designers of the resources (Jagtap, 2019). Human and natural resources could tackle the poverty problem. Forest ecosystem and forestbased resources are some of the natural resources for poverty alleviation. However, there is a lack of people's understanding of natural resources that requires intervention on the individual right, collective management, and empowerment as the alternatives in improving people's livelihood (Cheng et al. 2019). Countries with abundant natural resources could invest in poverty alleviation by managing natural resources sustainably and conserving them efficiently to generate economic benefits for the local community (Ayoo, 2007).

Indonesia is a country rich in natural resources, including forest and sea, but many Indonesian still live below the poverty line. It is due to various factors, namely limited land for agriculture, natural resources that are not managed properly, education level, and low skill level. Various problems causing those people to live below the poverty line were spread in various urban, rural, and archipelagic areas. The poverty of coastal communities in archipelagic areas is caused, among others, by the difficulty to access or reach the areas if the weather conditions are bad. It is also caused by the limited educational infrastructure as there were only elementary school and junior high school without any course institution and limited industries as workplaces. The coastal communities only depend on natural resources, which are fishery products. Their main occupations are fishermen and serving the tourists. If the weather is bad, they will face difficulties to earn a living for the family.

The effort to tackle the research problems was through entrepreneurship empowerment. Various ways are adopted to develop the coastal community through conservation area empowerment with community participation (Shinn, 2015). Tourism development could overcome the coastal communities' poverty problem. Local community participation in sustainable tourism development is based on community values (self-identity, sharing of wealth, cooperation, support of the weakest, spirituality, and harmony with nature) (Box and Africa, n.d.). A pro-poor approach must be able to empower the poor sustainably through practical intervention (Glavovic, 2007).

Empowerment is one of the strategies to promote the coastal communities' independence by improving entrepreneurial knowledge and skill (Panta \& Thapa, 2017) (Authors, 2017). There needs to be a sustainable infrastructure, social, and economic development for community (Firdaus et al. 2018). The number of entrepreneurs in Indonesia has only reached 3,1\% of the productive aged population. The number is considered low compared to the number in several developed countries which have reached $14 \%$ (www.cnnindonesia. com). In entrepreneurship, people need the knowledge to develop products and face obstacles in human resources, promotion, finance, administration, and innovation so that they could improve their business' competitiveness (Dewi et al. 2017).

Social entrepreneurship, as one of the alternatives, aims to improve business innovatively. Sustainability has an impact on public welfare by overcoming social and economic problems (Figueiredo and Franco, 2018). The main resources to create social values in tourism are natural, human, institutional, and political capital (Altinay et al. 2016). The resources are mobilized through the following strategies: 1) Stakeholder involvement and collaboration; 2) Relationship development and local community development (Altinay et al. 2016). 
This research aimed to identify the conceptual model, values, practices, and partners of social entrepreneurship in the archipelagic community. This research is also expected to identify social entrepreneurship empowerment strategies so that the archipelagic community could be empowered.

\section{METHODS}

This research used the qualitative method of narrative research approach (Gall and Borg, 2010). Narrative research not only recounts the events in the research participants' stories but also interprets them. It could be utilized for studies on individuals, organizations, groups, gurus, and communities. The data analysis in narrative research comprises identifying the keywords or key events found, organizing the events, interpreting them structurally, and associating them with the theories.

Kepuluan Seribu consists of two regions, namely Kepuluan Seribu Utara and Kepulauan Seribu Selatan, comprising Pulau Kelapa, Pulau Harapan, Pulau Panggang, Pulau Tidung, Pulau Pari, and Pulau Untung. This research was conducted in Pulau Untung Jawa for one year in 2019. The location and samples were determined based on particular objectives and criteria. The research sample criteria were as follows: a) An inhabited island or human settlement; b) The distance is relatively close from Jakarta; c) Transportations are available at all times; d) A tourism island; e) Having natural resources potentials; f) Unavailability of senior high school facilities; g) The fishermen develop coastal tourism businesses; h) The fishermen do not own fish farming businesses in the sea.

The data were collected using interview and observation guides. Interviews were conducted with the key informants which were tourism business owners and supporting informants which were public figures and government. Tourism business owners referred to water/ beach tourism business owners, owners of the beach bath equipment businesses, owners of food businesses on the beach, and owners of handicraft businesses. The public figures referred to the island custom leaders, Section Chief of Economic Community Empowerment and Welfare, and Head of Pulau Untung Jawa.

The data were analyzed through the stages of data collection, data reduction, data display, and conclusion drawing verification. The data were recorded carefully by providing codes to facilitate reduction and display to find important patterns or matters. Data coding consisted of data from business owners (A), government (B), public figures $(\mathrm{C} / \mathrm{C} 1)$, the head of the village $(\mathrm{B} 1)$, the section chief of empowerment (B2), general public on vacation to Pulau Untung Jawa (C2). The data were as follows: Water/beach tourism businesses (A1); beach bath equipment businesses (A2); food businesses (A3), handicraft businesses (A4).

\section{RESULTS}

\section{Potentials of Pulau Untung Jawa}

The archipelagic communities have different characteristics from those in urban and rural areas. Geographically, ships are needed to reach the islands. If the weather is bad, the travel to the islands must be postponed. The archipelagic communities are coastal communities that are prone to social and economic problems caused by environmental changes (Putten et al. 2016). There need to be various social policies to overcome the problems occurring in the community, as well as supports from formal and informal educational institutions to improve education and promote community participation to be empowered.

The coastal communities living in Kepuluan Seribu harness beaches for tourism which could be enjoyed by the general public particularly those from Jakarta. Pulau Untung Jawa is selected by the government as one of the tourism islands in Kepuluan Seribu because it has a relatively close distance and multiple alternatives for crossing to the island, namely crossing from Ancol (expensive), by government-owned ship, and community-owned ship. According to the criteria, Pulau Untung Jawa only had junior high school facilities and had varied local resources, such as breadfruit chips and candied cermai. The communities of Pulau Untung Jawa mostly worked as fishermen. The selection of Pulau Untung Jawa as a tourism island gives hope to the community to have additional jobs by serving beach tourism using boats, beach water games, water equipment rent, homestays, souvenirs, and culinary.

Pulau Untung Jawa has three citizen associations (rukun warga or RW). RW in Indonesia is the name of a community institution led by a head of RW chosen from community consensus. This institution 
is recognized and fostered by the government to be in charge of activities, life values, and community education based on mutual cooperation and kinship, as well as helping and facilitating the smoothness of tasks and development carried out by the government. The population of Pulau Untung Jawa was 2.333 people. The details are presented in Table 1.

Table 1. Population of Pulau Untung Jawa

\begin{tabular}{lccc}
\hline & RW 01 & RW 02 & RW 03 \\
\hline Male & 453 & 367 & 394 \\
Female & 448 & 323 & 348 \\
\hline
\end{tabular}

The communities of Pulau Untung Jawa generally worked as fishermen, but some of them worked in government and private institutions. The data of occupations obtained from the observation and interviews with the village party showed several occupations other than fisherman as shown in Table 2. Private employees have to cross to work, while Pulau Untung Jawa is their home.

Table 2. The occupations of Pulau Untung Jawa's community

\begin{tabular}{|c|c|}
\hline Occupations & $\begin{array}{l}\text { Number } \\
\text { (people) }\end{array}$ \\
\hline Other individual service providers (PJLP) & 227 \\
\hline Fishermen & 210 \\
\hline Entrepreneurs & 117 \\
\hline Private employees & 78 \\
\hline Civil servants & 32 \\
\hline TNI/Police & 8 \\
\hline Builder & 11 \\
\hline Shipbuilder & 5 \\
\hline Diver & 2 \\
\hline Total & 690 \\
\hline
\end{tabular}

Based on Table 2, being an entrepreneur was the prominent choice for Pulau Untung Jawa's community other than being a fisherman. It is in line with the social entrepreneurship concept as an approach to overcome social problems by creating social values and innovation. Social purpose is important in entrepreneurship practices. Social entrepreneurship creates a new generation of entrepreneurship by analyzing its historical perspective, development process, and characteristics (Kaneko, 2013). It has been defined as a process involving the innovative use and combination of resources to pursue opportunities to catalyze social change and/or address social needs (Littlewood and Holt, 2018). It drives pro-poor business growth and fulfills the needs of social businesses by engaging the government and private companies.

Developing social entrepreneurship requires human resources as an investment for business development in an area. A large number of human resources could be deployed as a strength in business development in the area. Human resources could be a long-term investment by providing educational services according to the needs. However, an alliance is needed in optimizing investment in human resources (Ferrary and Ferrary, 2015). The concept of investment in human resources is depicted in Figure 1.

\section{Human Resource Cycle}

Human resource quality determines a better occupation that would have an impact on income level. A higherincome level would lead to an investment in education and training which will affect human resource quality. An improved human resource quality would influence the environment, in the form of improved community quality and facilities and infrastructure (Zhao and Thompson, 2019). Pulau Untung Jawa has various human resources whose educational and skill quality could be improved and natural resources such as fish, beaches that could be managed into tourism, cermai, and breadfruits.

\section{Tourism Conscious Groupas SocialEntrepreneurship Motivator}

Being an entrepreneur becomes a way for Pulau Untung Jawa's community to increase income. The dominant indicator of being an entrepreneur is risktaking (Sucipto et al. 2015). The communities realize that business could not be carried out alone to handle the risks. The consumers are limited only in the island area, but the income will rise if there are visitors from outside the island. The communities have limitations in starting businesses, so the most appropriate way to start is by forming a business group so that the capital could be shared. The entrepreneurship community is part of a tourism conscious group (pokdarwis), which is called Pokdarwis Puja Berhias in Pulau Untung Jawa. Puja is the acronym for Pulau Untung Jawa and berhias is the acronym (in Indonesian) for clean, green, beautiful, safe, and cool. This group acts as a motivator, driver, and communicator to develop tourism businesses for public welfare improvement. 
This group formation is a strategy in developing social entrepreneurship. It is in line with the social entrepreneurship concept that consists of three elements: 1) Transformational capacity from collaborative practices in entrepreneurship put forward the collective dimension in entrepreneurship and reflect the organized social initiative capacity independently; 2) The processes of emergence, evolution, and learning taking place in social/activist movements and communitybased social initiatives; this requires in-depth, bottomup approaches that focus on people communities in action directly affected by austerity policies and not just activists' groups; 3) Type of collective entrepreneurs and their capacity to improve the vulnerable and marginalized community (Littlewood and Holt, 2018).

Tourism conscious group which includes entrepreneurship community has roles in motivating, facilitating, raising awareness of, mustering, and engaging community in its activities through socialization and coaching of $3 \mathrm{~A}$ principles in tourism, namely accessibility, attraction, and amenities. It plays a role to encourage the entrepreneurship community to have awareness in maintaining the coastal ecosystem, providing amenities for the tourists, and keeping the island clean. One of the amenity services for the tourists is Tourist Information Centre that provides information related to tourism, like beaches, culinary, homestays, and other facilities and infrastructures available on the island. There needs to be a routine group discussion among the members and stakeholders to achieve tourism consciousness. The stakeholders' engagement and awareness in the discussion give motivation and hope for the members to improve many facilities on the island.

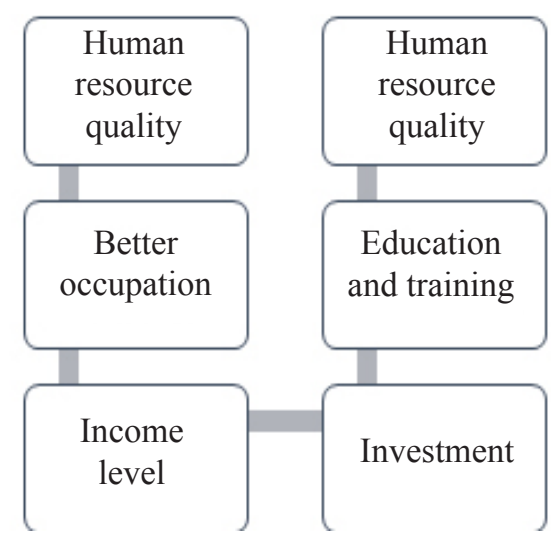

Figure 1. Human resource cycle
The entrepreneurship community could develop the community-based entrepreneurship empowerment effort by sharing knowledge with the community (Abdulkadir et al. 2018). It also encourages people to carry out social and economic activity through the empowerment facilitated by the entrepreneurship community. Its roles could encourage its members to improve themselves through various routine meetings as media to discuss many problems in business, join diverse types of training to improve their knowledge and skills in developing their businesses.

\section{Mutual Cooperation in Developing Social Entrepreneurship}

Social entrepreneurship becomes part of the group existing in the community that develops the tourism in Pulau Untung Jawa. The entrepreneurs hope many visitors would come for travelling so that their income from tourism would rise. The entrepreneurship community, which is part of a tourism conscious group, holds a festival on the anniversary of Pulau Untung Jawa which presents the local cultures and competitions, such as competition to decorate fishing boats for the fishermen, in which the most beautiful and cleanest one becomes the winner.

Besides bringing in the tourists by holding a festival, the development of facilities and infrastructures for beach tourism has damaged the coastal ecosystem, such as reduced mangrove forest and coral reefs in the development of rainbow bridge and beach widening for water tourism. The tourism conscious group consisting of the business owners realize the problem and collectively encourage the replanting of coral reefs under the bridge to maintain the coastal ecosystem.

Breadfruit and cermai that are widely available in Pulau Untung Jawa are processed into its local or typical foods. This business development engages housewives to work by producing breadfruit chips with a payment system based on the number of chips produced.

Social entrepreneurship in the communities of Pulau Untung Jawa has been seen in line with the social entrepreneurship concept in helping alleviate poverty and empowering the communities such as through business cooperation between food businesses, water tourism, and homestays. Local tourism has been developed through multiple types of training and the 
arrangement of merchant stalls on the seashore. It invites the tourists to maintain the beach environment by not throwing trash on the beach, inviting them to join voluntary work and other activities to keep the beach clean and beautiful. Those need mutual cooperation with the community.

Mutual cooperation, as the Indonesian local content, could become an attraction for the tourists to visit Indonesia, especially its villages and beaches. It is nothing new to people in the coastal area, especially on an island geographically far from urban life. Social entrepreneurship is an effort done in mutual cooperation. It attempts to share orders according to the products produced by the community. For example, beach tourism business owners share with homestays, food products, souvenirs, and other business owners. Social entrepreneurship could be developed based on the public characteristics, local content, local culture, and the roles of community that could be harnessed to perform social activities for poverty alleviation in the island. Social entrepreneurship places entrepreneurship that cannot be separated from the community as a strategy (Fortunato and Alter, 2015).

Social entrepreneurship could be developed in the coastal area by empowering the communities to establish tourism on the island through the entrepreneurship community. The tourism social entrepreneurship (TSE) model is suggested as a market-based strategy to address social problems whilst maximizing the benefits and minimizing the negative consequences that tourism may provide to host communities (Aquino et al. 2018). Social entrepreneurship developed in the community of Pulau Untung Jawa could use a group approach in empowering the communities through building tourism consciousness.

Based on the empirical results (Figure 2), the components that could improve social entrepreneurship in the archipelagic communities are potentials, a motivator, and mutual cooperation values. Potentials refer to human and natural resources in the form of seabased products that could be utilized by the community as local products. It is in line with Gamal and Biomed (2018) which stated that five components of social entrepreneurship are resources, networking, research and development, packaging, marketing, and branding, and leadership and entrepreneurship. A motivator is the role of the entrepreneurship community to encourage, help, and motivate its members to engage the communities in tourism business development.

Mutual cooperation values have existed in the community as social values to solve many problems faced by the community. The values are developed as the foundation of social entrepreneurship in the archipelagic communities by using cooperation, kinship, and consensus principles in developing business. This component generates social values in the community according to the goal of social entrepreneurship in helping solve problems in the community. Based on the empirical results, social entrepreneurship components in the archipelagic community have not run optimally, especially in terms of community partners. The obstacle encountered is in cooperating with various parties outside the island to help to promote the island's tourism and products.

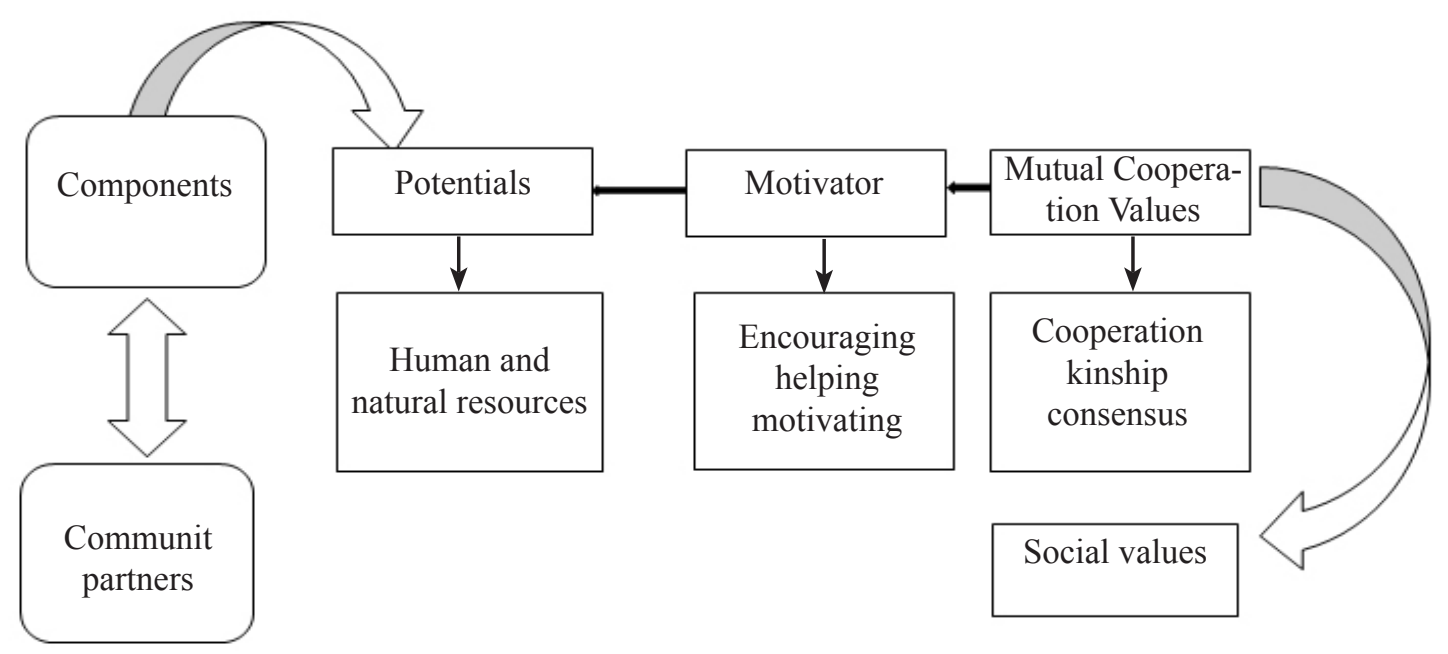

Figure 2. Social entrepreneurship model of archipelagic community 


\section{Managerial implications}

Social entrepreneurship practices need roles from multiple parties to solve social problems in the community. The parties are the community, academician, private sector, and stakeholders. Social entrepreneurship is a solution to solve problems by communicating with the stakeholders. While social entrepreneurs must make sense of their novel situations and create some kind of solution, this must also be communicated to other relevant stakeholders (Kimmitt and Muñoz, 2018). Based on the results of this research, creating social entrepreneurship in Pulau Untung Jawa needs a group approach by developing the following components: a) Human resources by providing entrepreneurial skill training; b) Local materials; c) Motivator's roles; d) Mutual cooperation values in developing business. The role of the private sector and government partners in facilitating business development is required through facilities and infrastructure assistance.

\section{CONCLUSIONS AND RECOMMENDATIONS}

\section{Conclusions}

People living in Pulau Untung Jawa face many obstacles in improving education and skills so that most of them work as fishermen. They find new hope since the island has been selected as a tourism island because they could increase their income from other sources other than being a fisherman. Social entrepreneurship strategy with group approach through tourism conscious group formed by the community is adopted. The components to develop social entrepreneurship are local potentials, a motivator, and mutual cooperation values. Social entrepreneurship could empower the community through social values built and community participation. It could impact the community's welfare through increasing skills in developing business in mutual cooperation, creating social values in the community, and engaging the community to do business collectively.

\section{Recommendations}

Social entrepreneurship is empirically proven to be able to empower the archipelagic communities in developing business. Social entrepreneurship is developed by improving human and natural resources as potentials utilized to develop tourism businesses and sea-based products. The role of the entrepreneurship community in motivating the members to engage in developing tourism businesses could be achieved through good cooperation between the members, government, and other partners in improving the knowledge and skills of the business owners. Mutual cooperation values that grow in the community become the foundation to develop social entrepreneurship with kinship and consensus principles. This social entrepreneurship model is expected to be implemented and made as a reference to improve public welfare in disadvantaged, remote, and outermost areas by sticking to the social values in the community.

\section{REFERENCES}

Abdulkadir JI, Madhakomala R, Idris F. 2018. Evaluation implementation of regional program empowering " gotong royong" in new autonomy region. International Journal of Scientific Research and Management 6(6): 181-202. https://doi.org/10.18535/ijsrm/v6i6.sh04

Altinay L, Sigala M, Waligo V. 2016. Social value creation through tourism enterprise. Tourism Management 54: 404-417. https://doi. org/10.1016/j.tourman.2015.12.011

Aquino RS, Lück M, Schänzel HA. 2018. Journal of Hospitality and Tourism Management A conceptual framework of tourism social entrepreneurship for sustainable community development. Journal of Hospitality and Tourism Management 37(September): 23-32. https://doi. org/10.1016/j.jhtm.2018.09.001

Ayoo C. 2007. Community-based natural resource management in Kenya. Management of Environmental Quality 18(5): 531-541. https:// doi.org/10.1108/14777830710778292

Cheng SH et al. 2019. A systematic map of evidence on the contribution of forests to poverty alleviation. Environmental Evidence 8: 1-22. https://doi. org/10.1186/s13750-019-0148-4

Dewi H, Maarif MS, Sunarti TC. 2017. Innovation strategy to improve the competitiveness of micro, small, and medium enterprises of bandar lampung banana chips. Indonesian Journal of Business and Entrepreneurship 3(1): 64-76. https://doi.org/10.17358/ijbe.3.1.64

Ferrary M, Ferrary M. 2015. Investing in transferable strategic human capital through alliances in the luxury hotel industry. Journal of Knowledge 
Management 19(5):1007-1028. https://doi. org/10.1108/JKM-01-2015-0045.

Figueiredo V, Franco M. 2018. Landuse policy wine cooperatives as a form of social entrepreneurship : Empirical evidence about their impact on society. Land Use Policy 79(January): 812-821. https:// doi.org/10.1016/j.landusepol.2018.09.022

Fortunato MW, Alter T. 2015. Community entrepreneurship development: an introduction. Community Development 46(5): 444-455. https:// doi.org/10.1080/15575330.2015.1080742

Jagtap S. 2019. Design and poverty: a review of contexts , roles of poor people, and methods. Research in Engineering Design 30(1): 41-62. https://doi. org/10.1007/s00163-018-0294-7

Kaneko I. 2013. Socialentrepreneurship in Japan : a historical perspective on current trends. Journal of Social Entrepreneurship 4(3):37-41. https:// doi.org/10.1080/19420676.2013.799085

Kimmitt J, Muñoz P. 2018. Sensemaking the 'social' in social entrepreneurship. International Small Business Journal: Researching Entrepreneurship 36(8): 859-886 https://doi. org/10.1177/0266242618789230

Littlewood D, Holt D. 2018. Socialentrepreneurship in south africa: exploring the influence of environment. Business \& Society 57(3): 525-561. https://doi.org/10.1177/0007650315613293.

Panta SK, Thapa B. 2017. Entrepreneurship and women's empowerment in gateway communities of Bardia National Park, Nepal. Journal of
Ecotourism 17(1): 1-23. https://doi.org/10.1080 /14724049.2017.1299743

Putten I. Van et al. 2016. The influence of community size and location on different dimensions of vulnerability: a case study of Australian coastal communities. Australian Geographer 48(1). https://doi.org/10.1080/00049182.2016.116872 7.

Shinn J. 2015. The rhetoric and reality of community empowerment in coastal conservation : a case study from Menai Bay Conservation Area. Tanzania 34(2): 107-124.

Sucipto E, Oktaviani R, Rizal R. 2015. The effects of partnership and entrepreneurship toward business performance of oyster mushroom (pleurotusostreatus). Indonesian Journal of Business and Entrepreneurship 1(1): 32-41. https://doi.org/10.17358/ijbe.1.1.32

Glavovic BC. 2007. Coastal sustainability an elusive pursuit ?:reflectionsonsouthafrica'scoastalpolicy experience. Coastal Management 34(1): 37-41. https://doi.org/10.1080/08920750500364914

Zhao Y, Thompson P. 2019. Investments in managerial human capital: Explanations from prospect and regulatory focus theories. International Small Business Journal: Researching Entrepreneurship 37(4): 365-394. https://doi. org/10.1177/0266242619828264 